\title{
ANALISIS STRUKTUR BALOK NON PRISMATIS MENGGUNAKAN METODE PERSAMAAN SLOPE - DEFLECTION
}

\author{
Agus Setiawan \\ Civil Engineering Department, Faculty of Engineering, Binus University \\ Jl. K.H. Syahdan No. 9, Palmerah, Jakarta Barat 11480 \\ agustinusset@yahoo.com
}

\begin{abstract}
Slope - deflection equation method is an analysis method to solve statically indeterminate structure. This method is a simple technique to analyze continuous beam, either prismatic or non prismatic. The technique for analyzing non prismatic beam is based on the prismatic beam concept, but with the introduce of some modification coefficient. These coefficients are available in some textbook discussing about structural analysis. This research has an objective to compare the analysis result of a continuous non prismatic beam, with slope deflection equation method, and result from a structural analysis program (i.e. SAP 2000 v.11.00). The internal moment at the joints produced from this two method will be compared each other. The results show that there is a small difference resulted in internal moment, obtained from hand calculation with slope - deflection method and from software output. The differences resulted from this two techniques are 2 up to 6\%. Based on this result it can be stated that slope-deflection method can be used to analyze statically indeterminate nonprismatic beam with some modification factors. The result obtained is nearly the same with one obtained from commercial softwares.
\end{abstract}

Keywords: slope-deflection method, non prismatic beam, internal moment

\begin{abstract}
ABSTRAK
Metode persamaan slope-deflection adalah salah satu metode analisis untuk menyelesaikan suatu struktur statis tak tentu. Metode sederhana ini menganalisis suatu struktur balok menerus, baik itu balok yang prismatis maupun non prismatis. Teknik untuk analisis balok non prismatis didasarkan pada konsep analisis balok prismatis, tapi menggunakan beberapa koefisien modifikasi. Koefisien-koefisien modifikasi ini dapat dijumpai dalam beberapa buku teks yang membahas tentang analisis struktur. Penelitian ini bertujuan membandingkan hasil analisis dari suatu balok menerus non prismatis menggunakan persamaan slopedeflection dan hasil dari output program SAP 2000 v.11.00. Variabel pembanding adalah hasil momen internal yang diperoleh dari kedua metode tersebut. Hasil analisis menunjukkan hanya terjadi perbedaan antara 2 hingga $6 \%$ dari kedua metode tersebut. Hasil tersebut menyatakan bahwa slope-deflection dapat digunakan untuk menganalisis suatu balok non prismatis statis tak tentu menggunakan beberapa faktor modifikasi. Hasil yang diberikan cukup mendekati hasil yang diperoleh menggunakan program komersial.
\end{abstract}

Kata kunci: slope-deflection, balok non prismatis, momen internal 


\section{PENDAHULUAN}

Dalam hal perencanaan struktur, pada umumnya seorang perencana struktur memilih bentuk struktur yang prismatis, artinya struktur yang memiliki penampang melintang yang seragam sepanjang bentangan struktur. Namun tidak jarang juga karena kebutuhan arsitektural, struktur tidak dapat memiliki penampang melintang yang seragam. Terkadang karena kebutuhan tinggi ruangan yang terbatas, berakibat tinggi elemen balok harus dibatasi pada suatu ukuran tertentu. Namun demikian dengan tidak mengurangi tingkat keamanan dari suatu elemen struktur balok, dapat saja pada tempattempat tertentu balok mempunyai tinggi yang lebih besar dari tempat lain pada bentangan yang sama. Jenis struktur balok dengan penampang melintang yang tidak seragam tersebut disebut dengan istilah balok non prismatis. Gambar 1 menunjukkan bentuk-bentuk balok non prismatik yang banyak digunakan.

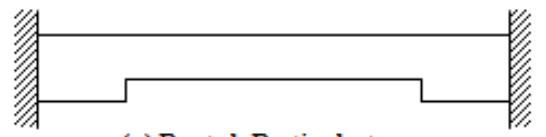

(a) Bentuk Bertingkat

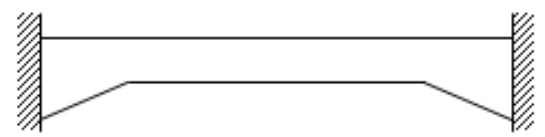

(b) Bentuk 'Tapered'

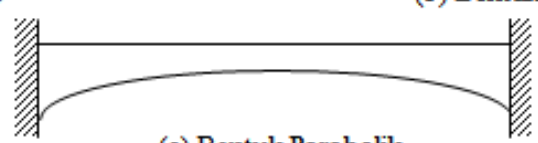

(c) Bentuk Parabolik

Gambar 1. Jenis-jenis balok non prismatis.

Salah satu metode yang dapat digunakan untuk menganalisis suatu struktur balok non prismatis, yaitu dengan menggunakan metode persamaan slope - deflection. Tujuan dari penelitian ini adalah untuk membandingkan cara analisis suatu balok non prismatis dengan menggunakan metode tersebut, serta hasil analisis menggunakana program bantu, dalam hal ini menggunakan software SAP 2000 v.11.00. Sedangkan manfaat yang diharapkan adalah agar dapat diperoleh suatu kepastian dalam hal analisis balok non prismatis dengan cara hand calculation maupun dengan bantuan software yang ada.

\section{METODE}

\section{Studi Pustaka}

Menurut Hibbeler (2006), hubungan antara kelengkungan balok dengan momen dan kekakuan lentur adalah:

$$
\frac{M}{E I}=\frac{1}{\rho}=v^{\prime \prime}
$$

dengan $E I$ adalah konstan untuk balok prismatis.

Untuk balok non prismatis, EI berubah menjadi suatu variabel sesuai dengan bentuk penampang balok. Apabila persamaan (1) diintegrasikan akan memberikan hubungan

$$
\theta \quad=v^{\prime}=\int \frac{M}{E I} d x
$$




$$
v \quad=\iint \frac{M}{E I} d x
$$

Seperti telah dijelaskan sebelumnya, terdapat dua macam metode yang dapat digunakan untuk melakukan analisis suatu struktur balok statis tak tentu yang memiliki penampang non prismatis. Kedua metode tersebut adalah metode persamaan slope - deflection dan metode momen distribusi, atau yang lebih dikenal dengan istilah metode Cross.

\section{Metode Persamaan Slope - Deflection}

Dari persamaan (2) dan (3), dapat diturunkan faktor kekakuan dan faktor pemindahan yang digunakan dalam metode analisis dengan persamaan slope - deflection, momen distribusi serta metode matriks kekakuan. Selanjutnya metode persamaan slope-deflection untuk suatu balok non prismatis dapat diturunkan dengan mengacu pada Gambar 2 berikut ini.

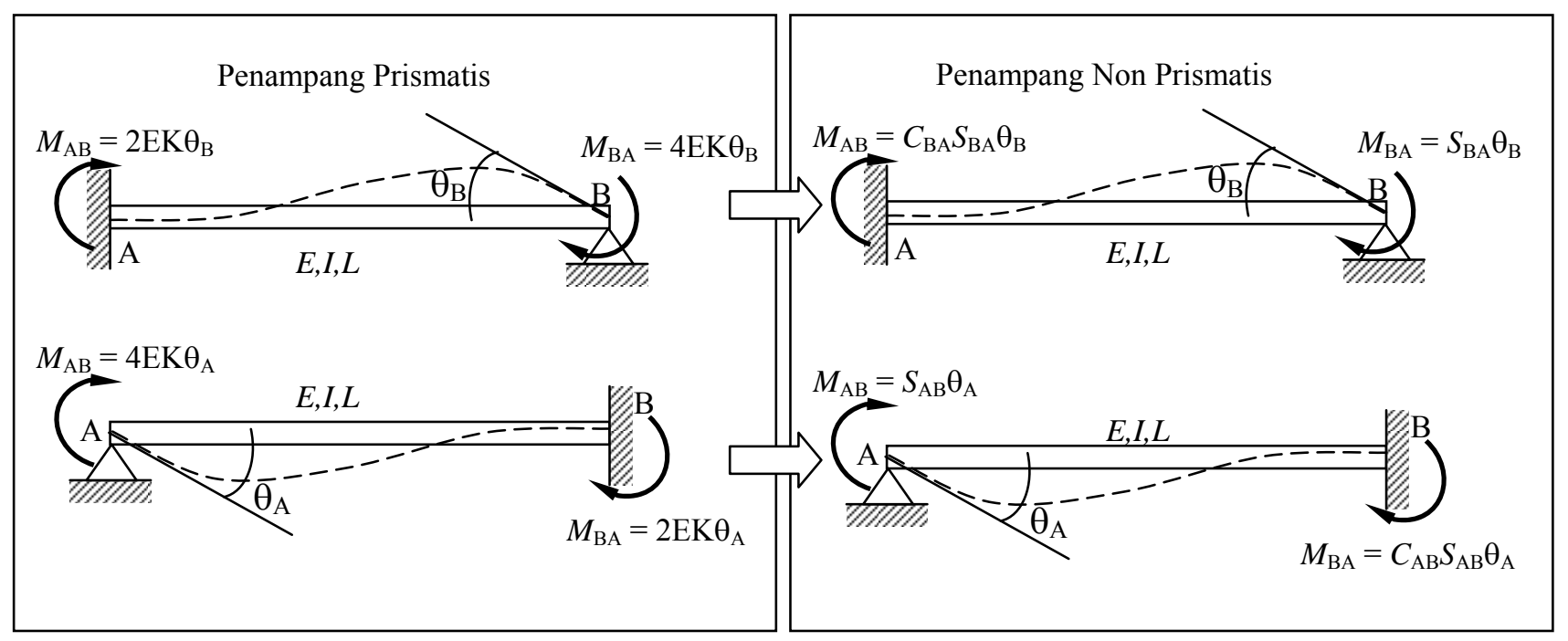

Gambar 2. Hubungan antara sudut rotasi dan momen pada titik.

Dalam Gambar 2 di atas,

$S_{\mathrm{AB}}=$ faktor kekakuan di titik A, yang sama dengan 4EK untuk balok prismatis

$C_{\mathrm{AB}}=$ faktor pemindahan dari titik A ke titik $\mathrm{B}$, sama dengan $1 / 2$ untuk balok prismatis

$S_{\mathrm{BA}}=$ faktor kekakuan di titik B, yang sama dengan 4EK untuk balok prismatis

$C_{\mathrm{BA}}=$ faktor pemindahan dari titik B ke titik A, sama dengan $1 / 2$ untuk balok prismatis

Nilai $S_{\mathrm{AB}}, C_{\mathrm{AB}}, S_{\mathrm{BA}}, C_{\mathrm{BA}}$ untuk balok non prismatis yang khusus ditampilkan dalam Tabel 1 (Mau, 2003). Dalam tabel tersebut juga dirumuskan besarnya Fixed End Moment untuk balok non prismatis. Selanjutnya dapat pula dituliskan hubungan antara $S_{\mathrm{AB}}, C_{\mathrm{AB}}, S_{\mathrm{BA}}$, $C_{\mathrm{BA}}$ sebagai berikut:

$$
C_{\mathrm{AB}} \cdot S_{\mathrm{AB}}=C_{\mathrm{BA}} \cdot S_{\mathrm{BA}}
$$

Efek dari rotasi balok, $\phi_{\mathrm{AB}}$ dapat digeneralisasi dengan cara yang sama seperti ditunjukkan dalam gambar berikut: 

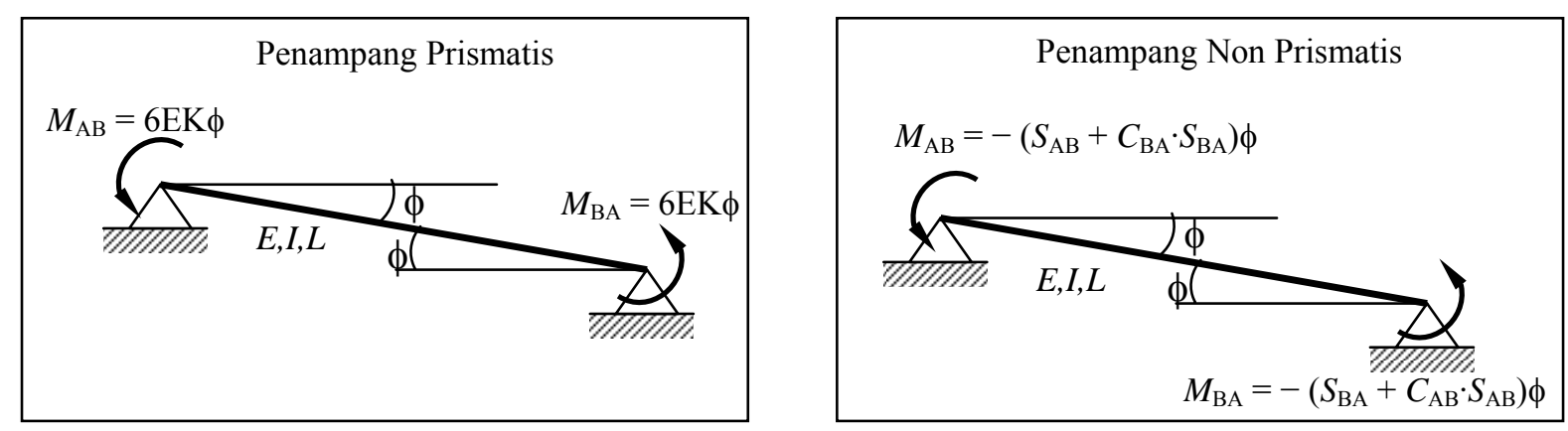

Gambar 3. Momen pada titik akibat rotasi balok. berikut:

Dengan menggunakan persamaan (4), momen pada titik ujung dapat dituliskan sebagai

$$
\begin{aligned}
& M_{\mathrm{AB}}=-S_{\mathrm{AB}}\left(1+C_{\mathrm{AB}}\right) \phi_{\mathrm{AB}} \\
& M_{\mathrm{BA}}=-S_{\mathrm{BA}}\left(1+C_{\mathrm{BA}}\right) \phi_{\mathrm{AB}}
\end{aligned}
$$

Selanjutnya dengan mengkombinasikan persamaan-persamaan dalam Gambar 2 dan 3, dapat dituliskan persamaan slope - deflection untuk suatu balok non prismatis sebagai berikut:

$$
\begin{aligned}
& M_{\mathrm{AB}}=S_{\mathrm{AB}} \theta_{\mathrm{A}}+C_{\mathrm{BA}} S_{\mathrm{BA}} \theta_{\mathrm{B}}-S_{\mathrm{AB}}\left(1+C_{\mathrm{AB}}\right) \phi_{\mathrm{AB}}+M_{\mathrm{AB}}^{\mathrm{F}} \\
& M_{\mathrm{BA}}=C_{\mathrm{AB}} S_{\mathrm{AB}} \theta_{\mathrm{A}}+S_{\mathrm{BA}} \theta_{\mathrm{B}}-S_{\mathrm{BA}}\left(1+C_{\mathrm{BA}}\right)+M_{\mathrm{BA}}^{\mathrm{F}}
\end{aligned}
$$

Dengan mengingat kembali persamaan (4), kedua persamaan tersebut dapat juga ditulis dalam bentuk:

$$
\begin{aligned}
M_{\mathrm{AB}} & =S_{\mathrm{AB}} \theta_{\mathrm{A}}+C_{\mathrm{AB}} S_{\mathrm{AB}} \theta_{\mathrm{B}}-S_{\mathrm{AB}}\left(1+C_{\mathrm{AB}}\right) \phi_{\mathrm{AB}}+M_{\mathrm{AB}}^{\mathrm{F}} \\
M_{\mathrm{BA}} & =S_{\mathrm{BA}} \theta_{\mathrm{B}}+C_{\mathrm{BA}} S_{\mathrm{BA}} \theta_{\mathrm{A}}-S_{\mathrm{BA}}\left(1+C_{\mathrm{BA}}\right) \phi_{\mathrm{AB}}+M_{\mathrm{BA}}^{\mathrm{F}}
\end{aligned}
$$

atau secara umum dapat dituliskan dalam bentuk:

$$
M_{\mathrm{N}}=S_{\mathrm{N}}\left(\theta_{\mathrm{N}}+C_{\mathrm{N}} \theta_{\mathrm{F}}-\left(1+\mathrm{C}_{\mathrm{N}}\right) \phi\right)+M_{\mathrm{N}}^{\mathrm{F}}
$$

dengan:

$M_{\mathrm{N}} \quad=$ momen internal di titik yang ditinjau, bernilai positif apabila searah jarum jam

$S_{\mathrm{N}} \quad=$ kekakuan absolut titik terdekat, yang dapat dihitung dari tabel 1

$\theta_{\mathrm{N}}, \theta_{\mathrm{F}}=$ sudut rotasi di titik dekat (Near) dan di titik jauh (Far), diukur dalam radian

$\phi \quad=$ sudut rotasi balok, apabila terdapat perpindahan $\Delta$ pada tumpuan, $\phi=\Delta / \mathrm{L}$

$M^{\mathrm{F}}{ }_{\mathrm{N}} \quad=$ nilai Fixed End Moment pada titik dekat, bernilai positif apabila searah jarum jam, dan nilainya dapat dilihat dalam Gambar 4.

\section{Lingkup Penelitian}

Untuk membandingkan hasil analisis balok non prismatis dengan menggunakan metode persamaan slope - deflection dengan hasil analisis dari SAP 2000, diambil suatu model contoh struktur balok non prismatis beserta beban yang bekerja seperti ditampilkan dalam Gambar 5. 


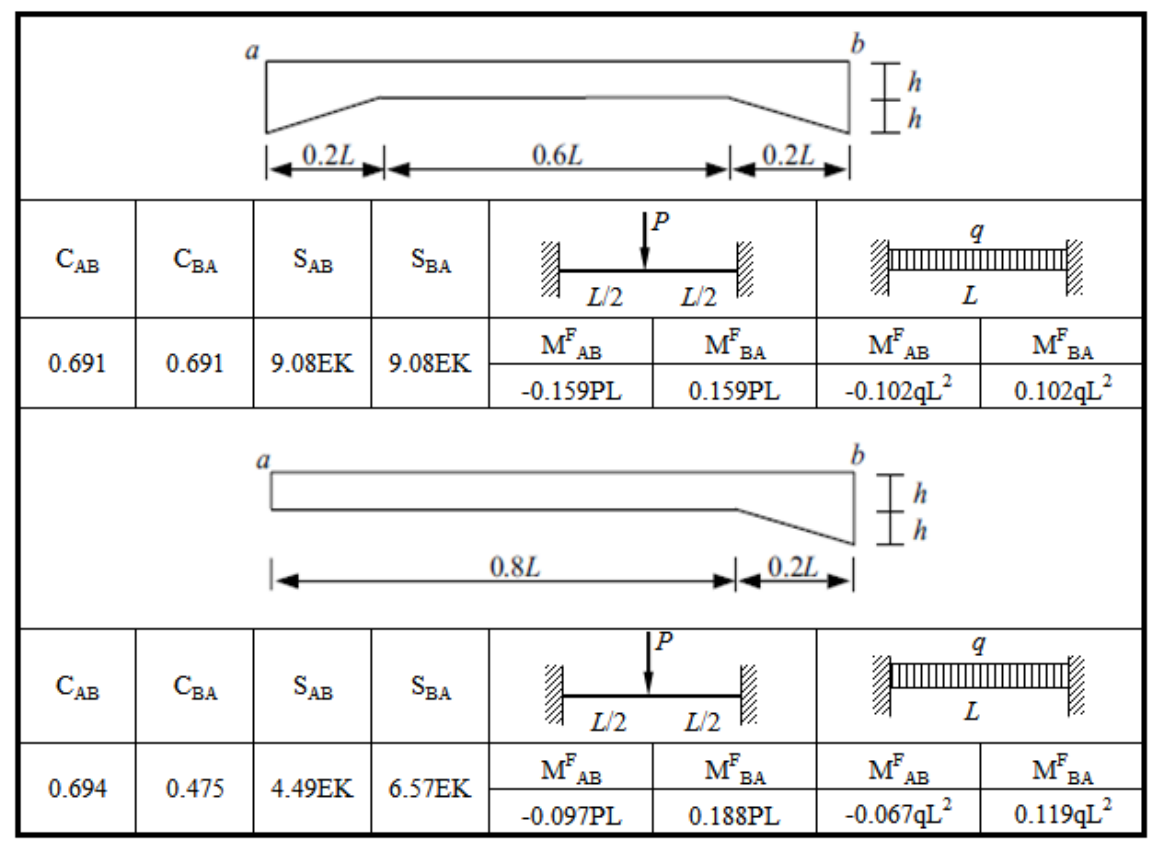

Gambar 4. Faktor kekakuan, faktor pemindahan dan fixed-end moment balok non prismatis.

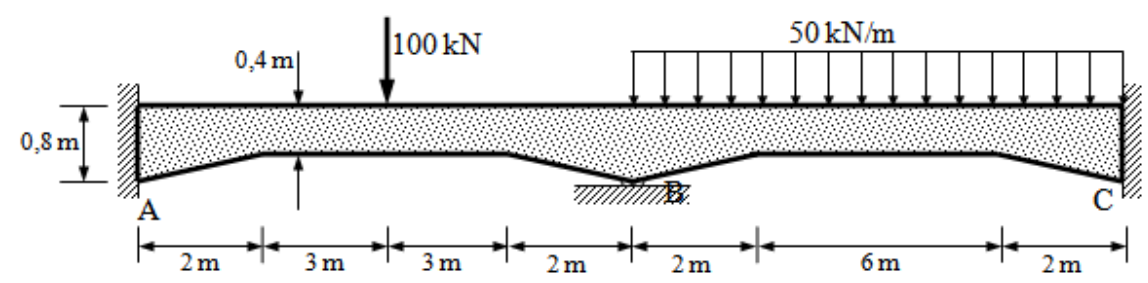

Gambar 5. Model struktur balok non prismatis.

Guna keperluan analisis, tebal struktur balok dianggap sebesar $300 \mathrm{~mm}$. Dan struktur tersebut terbuat dari material beton bertulang.

\section{HASIL DAN PEMBAHASAN}

Selanjutnya struktur balok dalam Gambar 5 tersebut akan dianalisis dengan menggunakan metode persamaan slope - deflection dan dengan menggunakan software SAP 2000 v.11.00.

\section{Analisis dengan Persamaan Slope - Deflection}

Fixed End Moment untuk balok $\mathrm{AB}$ dan $\mathrm{BC}$ dapat dihitung dengan menggunakan bantuan Gambar 4, yaitu:

$$
\begin{array}{ll}
\mathrm{M}_{\mathrm{AB}}^{\mathrm{F}}=-0,159 P L & =-0,159(100)(10)=-159 \mathrm{kN} \cdot \mathrm{m} \\
\mathrm{M}_{\mathrm{BA}}^{\mathrm{F}}=+0,159 P L & =+0,159(100)(10)=+159 \mathrm{kN} \cdot \mathrm{m} \\
\mathrm{M}_{\mathrm{BC}}^{\mathrm{F}}=-0,102 q L^{2} & =-0,102(50)(10)^{2}=-510 \mathrm{kN} \cdot \mathrm{m} \\
\mathrm{M}_{\mathrm{CB}}^{\mathrm{F}}=+0,102 q L^{2} & =+0,102(50)(10)^{2}=+510 \mathrm{kN} \cdot \mathrm{m}
\end{array}
$$


Selanjutnya momen internal di tiap titik dihitung dengan menggunakan persamaan (9):

$$
\begin{aligned}
M_{\mathrm{AB}} & =S_{\mathrm{AB}}\left(\theta_{\mathrm{A}}+C_{\mathrm{AB}} \theta_{\mathrm{B}}\right)+M_{\mathrm{AB}}^{\mathrm{F}}=9,08 E K\left(0+0,691 \theta_{\mathrm{B}}\right)-159 \\
& =6,274 E K \theta_{\mathrm{B}}-159 \\
M_{\mathrm{BA}} & =S_{\mathrm{BA}}\left(\theta_{\mathrm{B}}+C_{\mathrm{BA}} \theta_{\mathrm{A}}\right)+M_{\mathrm{BA}}^{\mathrm{F}}=9,08 E K\left(\theta_{\mathrm{B}}+0\right)+159 \\
& =9,08 E K \theta_{\mathrm{B}}+159 \\
M_{\mathrm{BC}} & =S_{\mathrm{BC}}\left(\theta_{\mathrm{B}}+C_{\mathrm{BC}} \theta_{\mathrm{C}}\right)+M_{\mathrm{BC}}^{\mathrm{F}}=9,08 E K\left(\theta_{\mathrm{B}}+0\right)-510 \\
& =9,08 E K \theta_{\mathrm{B}}-510 \\
M_{\mathrm{CB}} & =S_{\mathrm{CB}}\left(\theta_{\mathrm{C}}+C_{\mathrm{CB}} \theta_{\mathrm{B}}\right)+M_{\mathrm{CB}}^{\mathrm{F}}=9,08 E K\left(0+0,691 \theta_{\mathrm{B}}\right)+510 \\
& =6,274 E K \theta_{\mathrm{B}}+510
\end{aligned}
$$

Dengan memperhatikan kesetimbangan momen di titik B, jumlah dari $M_{\mathrm{BA}}$ dan $M_{\mathrm{BC}}$ harus sama dengan nol $\left(M_{\mathrm{BA}}+M_{\mathrm{BC}}=0\right)$, sehingga dengan substitusi nilai $M_{\mathrm{BA}}$ dan $M_{\mathrm{BC}}$ dari persamaan di atas akan dapat diperoleh:

atau

$$
\begin{aligned}
9,08 E K \theta_{\mathrm{B}}+159+9,08 E K \theta_{\mathrm{B}}-510 & =0 \\
18,16 E K \theta_{\mathrm{B}} & =351
\end{aligned}
$$

$$
\theta_{\mathrm{B}} \quad=19,328 /(E K)
$$

Setelah diperoleh nilai $\theta_{\mathrm{B}}$, dapat disubstitusikan kembali ke persamaan-persamaan untuk momen internal di atas, sehingga diperoleh:

$$
\begin{array}{llll}
M_{\mathrm{AB}}=-37,74 \mathrm{kN} \cdot \mathrm{m} & M_{\mathrm{BC}}=-334,5 \mathrm{kN} \cdot \mathrm{m} \\
M_{\mathrm{BA}}=+334,5 \mathrm{kN} \cdot \mathrm{m} & M_{\mathrm{CB}}=+631,3 \mathrm{kN} \cdot \mathrm{m}
\end{array}
$$

\section{Analisis dengan Software SAP 2000 v.11.00}

Selanjutnya hasil tersebut dibandingkan dengan output yang diperoleh dari hasil analisis struktur dengan menggunakan software SAP 2000 v.11.00. Penampang balok non prismatis yang dinamakan sebagai VAR1, memiliki properti sebagai berikut (Tabel 1):

Input beban merata pada balok BC ditunjukkan dalam Tabel $2-4$ berikut ini.

Input beban terpusat pada balok AB ditunjukkan dalam Tabel 5 dan 6 berikut:

Tabel 1

Frame Section Properties 05 - Non Prismatic, Part 1 of 2

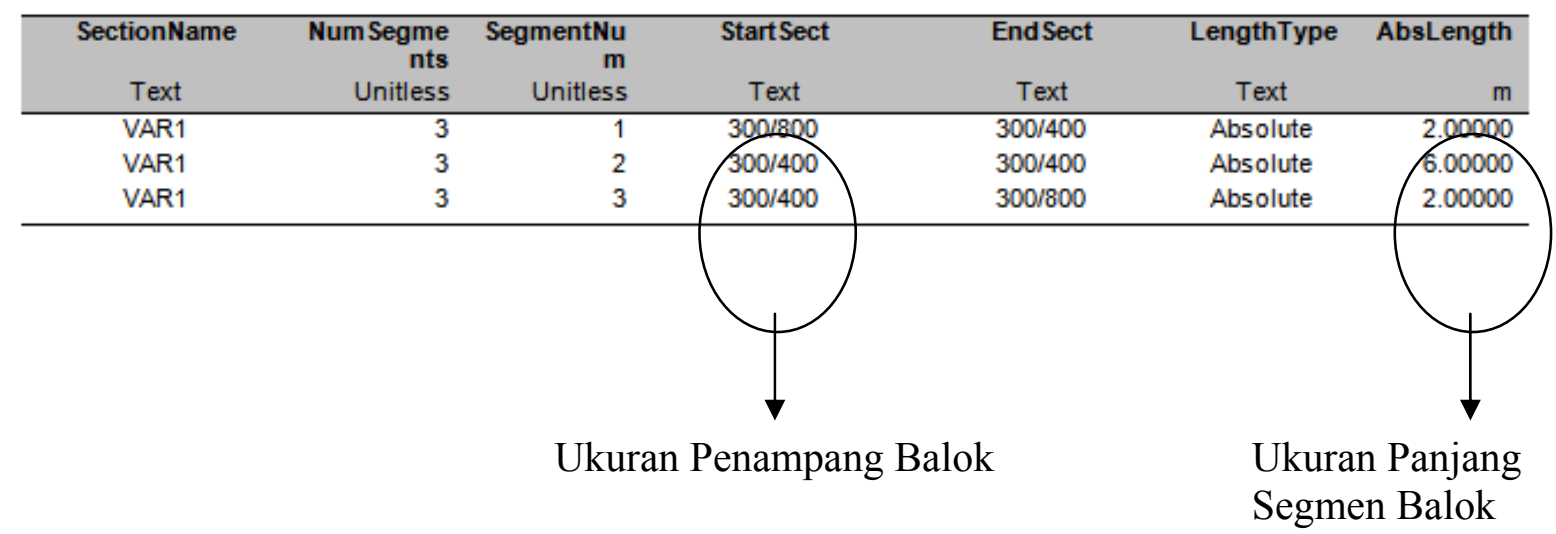


Tabel 2

Frame Loads - Distributed, Part 1 of 3

\begin{tabular}{|c|c|c|c|c|c|c|}
\hline $\begin{array}{c}\text { Frame } \\
\text { Text }\end{array}$ & $\begin{array}{c}\text { LoadCase } \\
\text { Text }\end{array}$ & $\begin{array}{l}\text { CoordSys } \\
\text { Text }\end{array}$ & $\begin{array}{l}\text { Type } \\
\text { Text }\end{array}$ & $\begin{array}{c}\text { Dir } \\
\text { Text }\end{array}$ & $\begin{array}{l}\text { DistType } \\
\text { Text }\end{array}$ & $\begin{array}{r}\text { RelDistA } \\
\text { Unitless }\end{array}$ \\
\hline 2 & DEAD & GLOBAL & Force & Gravity & RelDist & 0.0000 \\
\hline
\end{tabular}

Tabel 3

Frame Loads - Distributed, Part 2 of 3

\begin{tabular}{ccrrrrr}
\hline $\begin{array}{c}\text { Frame } \\
\text { Text }\end{array}$ & $\begin{array}{c}\text { LoadCase } \\
\text { Text }\end{array}$ & $\begin{array}{r}\text { RelDistB } \\
\text { Unitless }\end{array}$ & $\begin{aligned} \text { AbsDistA } \\
\mathrm{m}\end{aligned}$ & $\begin{aligned} \text { AbsDistB } \\
\mathrm{m}\end{aligned}$ & $\begin{array}{r}\text { FOverLA } \\
\mathrm{KN} / \mathrm{m}\end{array}$ & $\begin{array}{r}\text { FOverLB } \\
\mathrm{KN} / \mathrm{m}\end{array}$ \\
\hline 2 & DEAD & 1.0000 & 0.00000 & 10.00000 & 50.00 & 50.00 \\
\hline
\end{tabular}

Tabel 4

Frame Loads - Distributed, Part 3 of 3

\begin{tabular}{ccc}
\hline $\begin{array}{c}\text { Frame } \\
\text { Text }\end{array}$ & $\begin{array}{c}\text { LoadCase } \\
\text { Text }\end{array}$ & $\begin{array}{c}\text { GUID } \\
\text { Text }\end{array}$ \\
\hline 2 & DEAD & \\
\hline
\end{tabular}

Tabel 5

Frame Loads - Point, Part 1 of 2

\begin{tabular}{|c|c|c|c|c|c|c|}
\hline $\begin{array}{c}\text { Frame } \\
\text { Text }\end{array}$ & $\begin{array}{c}\text { LoadCase } \\
\text { Text }\end{array}$ & $\begin{array}{l}\text { CoordSys } \\
\text { Text }\end{array}$ & $\begin{array}{l}\text { Type } \\
\text { Text }\end{array}$ & $\begin{array}{c}\text { Dir } \\
\text { Text }\end{array}$ & $\begin{array}{l}\text { DistType } \\
\text { Text }\end{array}$ & $\begin{array}{r}\text { RelDist } \\
\text { Unitless }\end{array}$ \\
\hline 1 & DEAD & GLOBAL & Force & Gravity & RelDist & 0.5000 \\
\hline
\end{tabular}

Tabel 6

Frame Loads - Point, Part 2 of 2

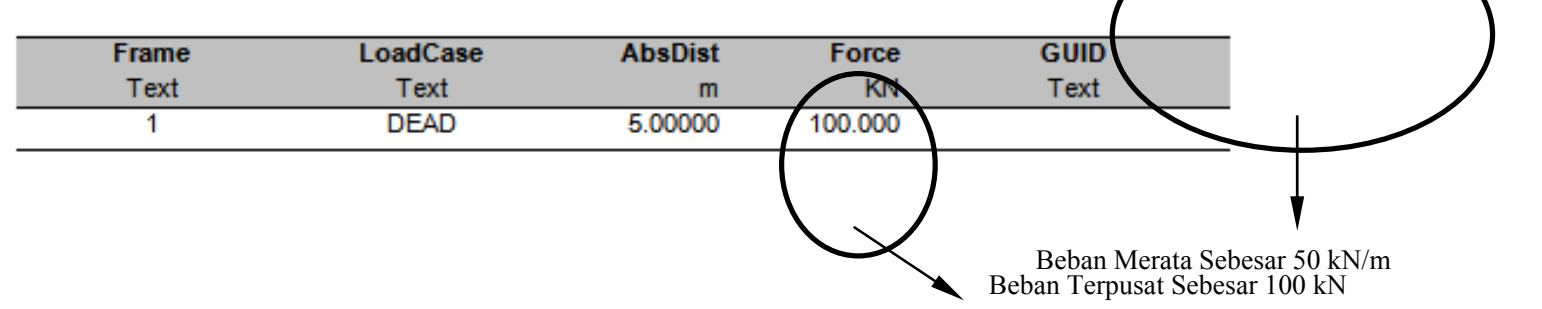

Secara lengkap pemodelan struktur dan pembebanannya dengan menggunakan SAP 2000 v.11.00 ditunjukkan dalam Gambar 6 di bawah ini.

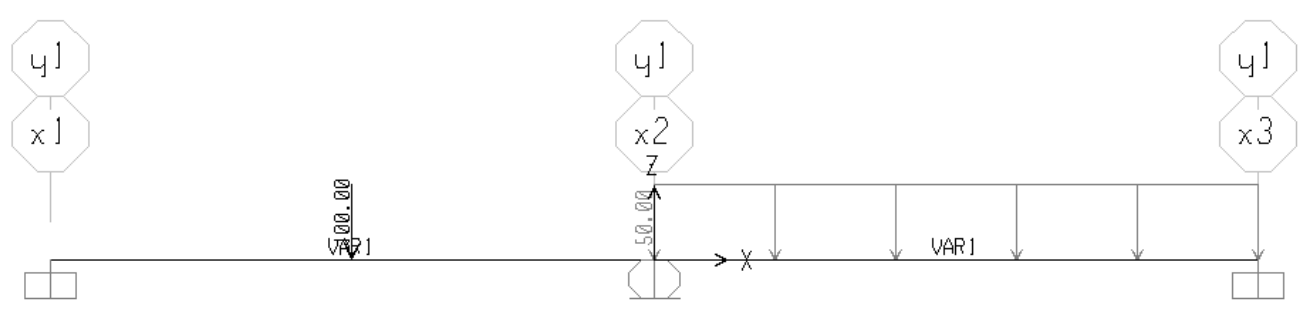

Gambar 6. Pemodelan struktur balok menerus non prismatis. 
Setelah dilakukan running program, hasil output untuk momen internal pada titik A, B dan C dapat dilihat pada Tabel 7 berikut:

Tabel 7

Element Joint Forces - Frames, Part 1 of 2

\begin{tabular}{|c|c|c|c|c|c|c|c|c|}
\hline Frame & Joint & OutputCase & CaseType & F1 & $F 2$ & F3 & M1 & M2 \\
\hline Text & Text & Text & Text & $\mathrm{KN}$ & $\mathrm{KN}$ & $\mathrm{KN}$ & $\mathrm{KN}-\mathrm{m}$ & $\mathrm{KN}-\mathrm{m}$ \\
\hline 1 & 1 & DEAD & LinStatic & 0.000 & 0.000 & 21.378 & 0.0000 & -40.3797 \\
\hline 1 & $\sim 1$ & DEAD & LinStatic & 0.000 & 0.000 & -21.378 & 0.0000 & $-2.3 / 56$ \\
\hline 1 & $\sim$ & DEAD & LinStatic & 0.000 & 0.000 & 21.378 & 0.0000 & 2.3756 \\
\hline 1 & -2 & DEAD & Linstatic & 0.000 & 0.000 & 78.622 & 0.0000 & 169.3586 \\
\hline 1 & $\sim 2$ & DEAD & LinStatic & 0.000 & 0.000 & .78 .622 & 0.0000 & $-169,3586$ \\
\hline 1 & 2 & DEAD & LinStatic & 0.000 & 0.000 & 78.622 & 0.0000 & 326.6033 \\
\hline 2 & 2 & DEAD & LinStatic & 0.000 & 0.000 & 221.378 & 0.0000 & -326.6033 \\
\hline 2 & -3 & DEAD & LinStatic & 0.000 & 0.000 & -121.378 & 0.0000 & -16.1520 \\
\hline 2 & -3 & DEAD & Linstatic & 0.000 & 0.000 & 121.378 & 0.0000 & 16.1520 \\
\hline 2 & -4 & DEAD & LinStatic & 0.000 & 0.000 & 178.622 & 0.0000 & 155.5822 \\
\hline 2 & -4 & DEAD & LinStatic & 0.000 & 0.000 & -178.622 & 0.0000 & -155.5822 \\
\hline 2 & 3 & DEAD & LinStatic & 0.000 & 0.000 & 278.622 & 0.0000 & 612.8269 \\
\hline
\end{tabular}

Dari hasil output diperoleh besarnya momen internal di titik A, B dan C sebagai berikut:

$$
\begin{array}{llll}
M_{\mathrm{AB}} & =-40,38 \mathrm{kN} \cdot \mathrm{m} & M_{\mathrm{BC}} & =-326,6 \mathrm{kN} \cdot \mathrm{m} \\
M_{\mathrm{BA}} & =+326,6 \mathrm{kN} \cdot \mathrm{m} & M_{\mathrm{CB}} & =+612,83 \mathrm{kN} \cdot \mathrm{m}
\end{array}
$$

Apabila dirangkum, dapat dibandingkan hasil analisis dengan metode slope - deflection dan hasil dari output software SAP 2000 v.11.00 sebagai berikut (Tabel 8):

Tabel 8

Perbandingan Nilai Momen Internal

\begin{tabular}{crrc}
\hline Momen Internal & Slope-Deflection & SAP 2000 v.11.00 & Selisih (\%) \\
\hline$M_{\mathrm{AB}}$ & $-37,74 \mathrm{kN} \cdot \mathrm{m}$ & $-40,38 \mathrm{kN} \cdot \mathrm{m}$ & 6,54 \\
$M_{\mathrm{BA}}$ & $+334,5 \mathrm{kN} \cdot \mathrm{m}$ & $+326,6 \mathrm{kN} \cdot \mathrm{m}$ & 2,42 \\
$M_{\mathrm{BC}}$ & $-334,5 \mathrm{kN} \cdot \mathrm{m}$ & $-326,6 \mathrm{kN} \cdot \mathrm{m}$ & 2,42 \\
$M_{\mathrm{CB}}$ & $+631,3 \mathrm{kN} \cdot \mathrm{m}$ & $+612,83 \mathrm{kN} \cdot \mathrm{m}$ & 3,01 \\
\hline
\end{tabular}

Dari rangkuman perbandingan hasil analisis balok prismatis seperti ditampilkan dalam Tabel 8 di atas, dapat ditemukan bahwa terdapat perbedaan kecil saja, antara cara analisis dengan menggunakan persamaan slope - deflection dan cara analisis dengan menggunakan program bantu SAP 2000. Perbedaan output momen internal yang dihasilkan dari kedua cara ini hanya berkisar antara 2 hingga $6 \%$.

\section{PENUTUP}

Dari hasil analisis dan pembahasan yang telah dilakukan, dapat diambil beberapa kesimpulan sebagai berikut: (1) perbedaan hasil analisis balok statis tak tentu non prismatis dengan cara hand calculation menggunakan metode slope - deflection dan dengan bantuan software SAP 2000, hanya menunjukkan perbedaan yang kecil dan tidak terlalu signifikan, yaitu pada kisaran 2 hingga 6\%; (2) metode persamaan slope - deflection dapat digunakan untuk menganalisis suatu struktur balok statis tak tentu dengan bentuk penampang yang tidak prismatis, menggunakan beberapa koefisien modifikasi; (3) pemodelan yang tepat dengan menggunakan software SAP 2000 akan menghasilkan output yang akurat pula. 


\section{DAFTAR PUSTAKA}

CSI. (2007). CSI Analysis Reference Manual For SAP 2000. California: Computers and Structures.

Hibbeler, R.C. (2006). Structural Analysis, (6 ${ }^{\text {th }}$ ed.). Singapore: Pearson Prentice Hall.

Leet, K.M. \& Chia, M.H. (2005). Fundamental of Structural Analysis, ( $2^{\text {nd }}$ ed.). Singapore: McGraw Hill. 